\title{
Geophysical survey of geothermal energy potential in the Liaoji Belt, northeastern China
}

\author{
Chong Peng 1,2,3, Baozhi Pan ${ }^{1}$, Linfu Xue $2^{2^{*}}$ (D) and Haiyan Liu³
}

*Correspondence:

pc512516@163.com

${ }^{2}$ College of Earth Sciences,

Jilin University, 2199 Jianshe

Street, Changchun 130061,

People's Republic of China

Full list of author information

is available at the end of the

article

\begin{abstract}
The Liaodong area which lies in the Liaoji Belt of northeastern China is rich in geothermal resources, but locating the resources is challenging. Here non-seismic geophysical data, existing geological data and the physical properties of rocks are examined to locate and characterise potential geothermal resources. High-precision gravity, aeromagnetic and magnetotelluric data are analysed to determine the characteristics of the hidden faults in the region and map the spatial distribution of the subsurface rock mass and its properties. The distribution of hidden faults and the basic characteristics of the rock mass were determined via Euler deconvolution of the gravity and aeromagnetic data. The subsurface extension of concealed faults, the spatial distribution of intrusive rocks, and the specific locations of underground thermal storage structures were determined from magnetotelluric data analysis, thereby enabling geothermal energy targets to be identified. The results highlight four potential sites of geothermal energy development in the study area, which indicate that non-seismic geophysical data can provide reliable clues to the geothermal energy potential in a given region.
\end{abstract}

Keywords: Liaoji Belt, Gravity, Aeromagnetic, Magnetotelluric, Liaodong area, Geothermal resource

\section{Introduction}

Economic development has accelerated the consumption of oil, natural gas, coal and other traditional energies, leading to the depletion of traditional fossil fuel resources, heavy pollution and degradation of the natural environment (Dincer and Acar 2015; Li and Xue 2015). Therefore, there is a growing need for clean energy (Fridleifsson 2001). Geothermal energy is one of the most important clean energy options that has attracted growing attention worldwide (Barbier 2011). Geothermal resources have the advantage over traditional fossil fuels of possessing large reserves that are clean and environmentally friendly (Kütahyali et al. 2011; Croteau and Gosselin 2015). An increase in the global use of geothermal resources would reduce the emissions of particulate matter and harmful gases that result from the combustion of fossil fuels (Lior 2010).

Researchers have developed and implemented various methods to investigate the potential reserves and exploitation of geothermal resources with promising results. For example, geophysical methods have been employed to predict the geothermal potential of the Baja California Peninsula (Arango-Galván et al. 2015); deep-buried faults in geothermal regions have been successfully identified using microtremor arrays (Xu et al. 
2012); and gravity and magnetic data (Mohammadzadeh Moghaddam et al. 2016; Abdel Zaher et al. 2018), as well as magnetotelluric soundings (Zhang et al. 2015; Hersir et al. 2018), have been acquired and analysed to infer geothermal energy potential. The North China Craton, one of the oldest cratonic blocks in the world (Liu et al. 1992; Song et al. 1996), has been intensively studied in terms of its geothermal energy potential, with the Liaoji Belt attracting considerable attention (Zhang 1984; Peng and Palmer 1995; Li and Zhao 2007; Li and Chen 2014; Yuan et al. 2015). Previous geochemical analyses have suggested that the heat generation rate of the intrusive rocks throughout the belt is relatively high, which could provide the heat source for the formation of geothermal resources (Wang and Huang 1990; Hu et al. 2001; Li and Xue 2015).

Therefore, we analysed our non-seismic geophysical data using Euler deconvolution to investigate the geothermal energy potential in the Liaoji Belt. Euler deconvolution of the gravity and magnetic data provided a better characterisation of the highlighted structures and delineated the extent of the geothermal source. Euler deconvolution was selected because it is a fast inversion and interpretation method for gravity and magnetic potential field data that can automatically determine the location of the field source without any a priori information, and effectively delineate the location, depth and spatial distribution of fractures in a rock mass.

Therefore, we present the first investigation of the geothermal energy potential of the Liaoji Belt (Fig. 1) via the integration of geological and non-seismic geophysical data to determine the thermal structure of the area and delineate geothermal targets.

\section{Geological setting}

The study area is located in the Liaodong region, which lies in the northern Jiao-LiaoJi Belt of the North China Craton, northeastern China (Fig. 1). The Liaoji palaeo-belt is a relatively complete and preserved Palaeoproterozoic zone that possesses favourable geological conditions for mineralisation. It has undergone a complex tectonic evolution, including uplift, subsidence, arching and rifting, with metamorphism and deformation at different scales within the rift, as well as the formation of complex folds and deepseated faults (Lu et al. 1998; Zhao et al. 2001, 2005; Zhao 2009; Li et al. 2006; Wan et al. 2006; Lu et al. 2006; Tam et al. 2011; Meng et al. 2013). Repeated, intense episodes of magmatism in the Liao Ji rift produced large intrusive rock masses, with intense hydrothermal-exhalation along deep-seated faults (Zhao et al. 2001, 2005; Zhao 2009; Li et al. 2005, 2006, 2011, 2012; Zhao et al. 2012; Zhao and Zhai 2013; Peng et al. 2016a). The region is rich in geothermal resources, with measured geothermal water temperatures and flow rates of up to $70{ }^{\circ} \mathrm{C}$ and $4 \mathrm{~kg} / \mathrm{s}$ (Zhong and Xiao 1990; Table 1).

Previous heat flow estimates for the North China Craton are in the range of 29.7$113.9 \mathrm{~mW} / \mathrm{m}^{2}$ (He 2015), with the eastern North China Craton possessing a high background heat flow of $\sim 63 \mathrm{~mW} / \mathrm{m}^{2}$ (Jiang et al. 2019). The heat flow estimate for the Liaodong area is $\sim 56.97 \mathrm{~mW} / \mathrm{m}^{2}$, which is lower than the continental average in China, with the granites, faulted areas, and older metamorphic rocks yielding values of 55.790.4, 64.9-72.0, and 32.1-49.0 $\mathrm{mW} / \mathrm{m}^{2}$ ( $\mathrm{Li}$ et al. 2014; Li 2015; Fig. 1), respectively. Furthermore, the geothermal gradient in the Liaodong area is only $20{ }^{\circ} \mathrm{C} / \mathrm{km}(\mathrm{Li}$ et al. 2014; Li and Xue 2015). We, therefore, infer that radiogenic heat from the granites is the heat source (Zhong and Xiao 1990; Liu et al. 2014; Li et al. 2014; Li and Xue 2015), 


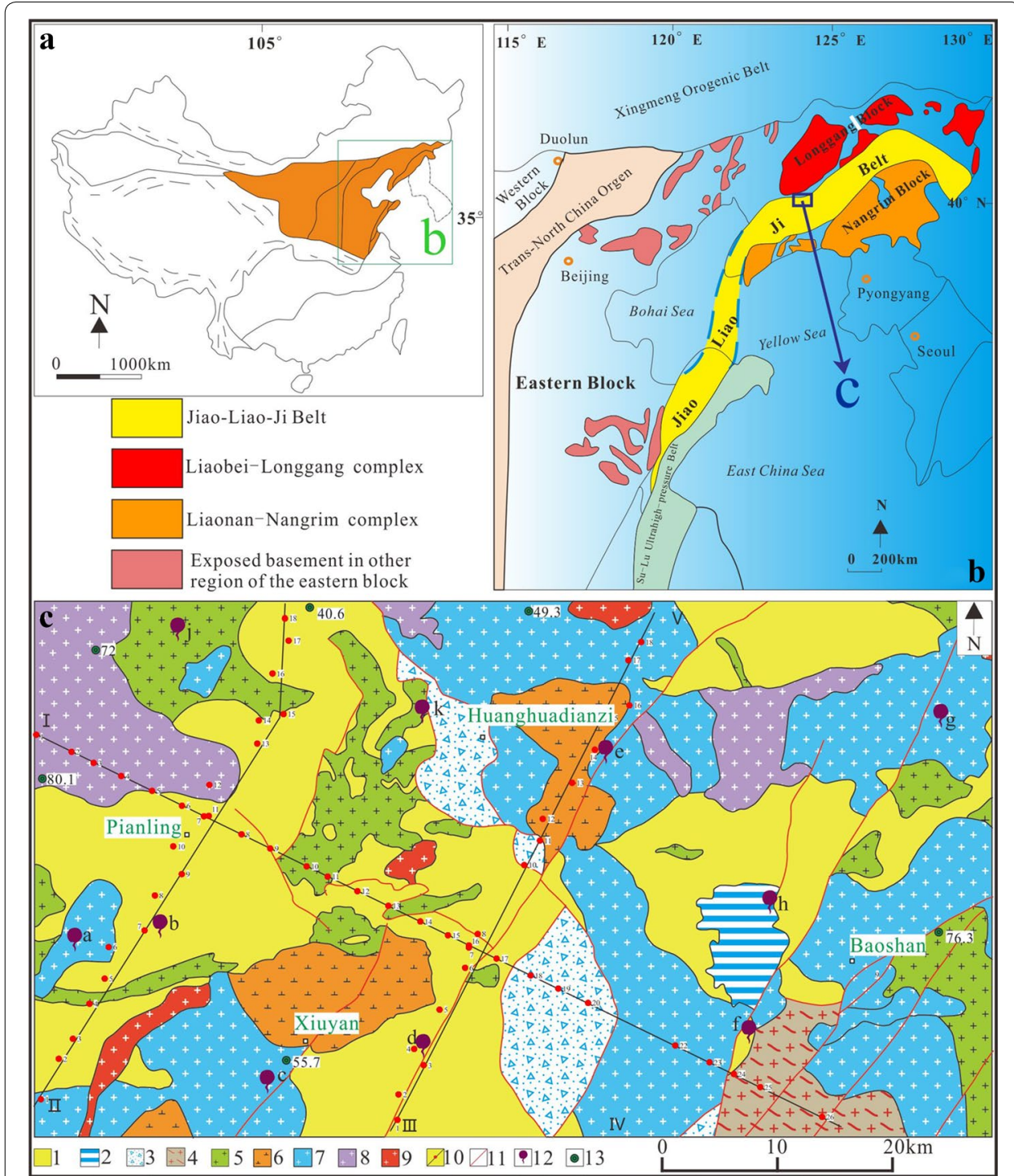

Fig. 1 Tectonic setting of the NCC (a), regional map of the Precambrian geology of the Eastern Block in the NCC (b) and Simplified geological map of the study area (c), modified after Zhao et al. (2005) and Peng et al. (2016a). 1. Paleozoic. 2. Permian. 3. Jurassic. 4. Archean granitic gneiss. 5. Paleoproterozoic granite. 6. Early Triassic diorite. 7. Middle Triassic granite. 8. Jurassic granite. 9. Cretaceous granite. 10. Locations of MT measurement lines and points. 11. Fault. 12. Hot spring. 13. Heat flow values

with the 10-km-deep zone of radiogenic heating generated by these shallow intrusive rocks playing a major role in the formation of the geothermal resources. For example, the rate of radiogenic heat generation in the mantle and the lower crust is low, which has little influence on the heat flow at the surface. Recent studies have confirmed that the geothermal resources in the Liaodong area are derived primarily from radiogenic heat generation in granite of various ages. Most of the hot springs that have recently been found in the Liaodong area occur above intrusive rocks and in areas that have undergone tensional fracturing (Fig. 1), producing mainly NW-SE-trending normal faults (Liu et al. 2014; Li and Xue 2015). The intrusive rocks provide the heat that forms the geothermal 
Table 1 List of hot springs in the Liaodong area

\begin{tabular}{lllll}
\hline Number & Position & & Temperature $\left({ }^{\circ} \mathbf{C}\right)$ & $\begin{array}{l}\text { Flow rates } \\
(\mathbf{k g} / \mathbf{s})\end{array}$ \\
\hline $\mathrm{a}$ & & & - \\
$\mathrm{b}$ & $123^{\circ} 03^{\prime} \mathrm{E}$ & $040^{\circ} 23^{\prime} \mathrm{N}$ & 60 & 1.39 \\
$\mathrm{c}$ & $123^{\circ} 09^{\prime} \mathrm{E}$ & $040^{\circ} 24^{\prime} \mathrm{N}$ & 50 & 0.97 \\
$\mathrm{~d}$ & $123^{\circ} 25^{\prime} \mathrm{E}$ & $040^{\circ} 18^{\prime} \mathrm{N}$ & 48 & - \\
$\mathrm{e}$ & $123^{\circ} 15^{\prime} \mathrm{E}$ & $040^{\circ} 16^{\prime} \mathrm{N}$ & 47 & 4.00 \\
$\mathrm{f}$ & $123^{\circ} 36^{\prime} \mathrm{E}$ & $040^{\circ} 32^{\prime} \mathrm{N}$ & 70 & 0.97 \\
$\mathrm{~g}$ & $123^{\circ} 45^{\prime} \mathrm{E}$ & $040^{\circ} 18^{\prime} \mathrm{N}$ & 46 & 3.33 \\
$\mathrm{~h}$ & $123^{\circ} 56^{\prime} \mathrm{E}$ & $40^{\circ} 46^{\prime} \mathrm{N}$ & 32 & 0.42 \\
$\mathrm{j}$ & $123^{\circ} 46^{\prime} \mathrm{E}$ & $40^{\circ} 25^{\prime} \mathrm{N}$ & 31 & 1.00 \\
$\mathrm{k}$ & $123^{\circ} 11^{\prime} \mathrm{E}$ & $40^{\circ} 61^{\prime} \mathrm{N}$ & 48 & 0.97 \\
\hline
\end{tabular}

resources in the Liaodong area, and the dense distribution of fractures provides migration pathways that enable the development of geothermal resources at the surface.

\section{Methods}

An effective geophysical interpretation of geothermal potential requires a petrophysical analysis of the relevant rocks (Huang et al. 1998; Li and Chen 2013). Therefore, we used data (Table 2) from Peng et al. (2016a) and divided them into three classes (high/strong, intermediate and low/weak; Li and Chen 2013; Peng et al. 2016a; Table 3). We also summarised the physical characteristics of the strata and intrusive rocks ( $\mathrm{Li}$ and Chen 2013; Peng et al. 2016a; Table 4), revealing that the resistivity of the intrusive rocks is generally higher than that of the sedimentary rocks and that the density of the intrusive rocks is generally lower than that of the sedimentary rocks.

\section{Gravity data}

The gravity data were obtained from the Geological Survey of China. Gravity measurements were made at $~ 500-\mathrm{m}$ intervals across the study area using a CG-5 AutoGrav gravimeter (Scintrex, Canada) and data from 1543 gravity survey stations. The survey stations were located mainly along the road and track network in the study area, with the preliminary positions determined using 1:50,000 topographic maps. Planimetric and altimetric measurements of the gravity survey points were obtained using a Wild T0 Tacheometer Theodolite (Wild Heerbrugg, Switzerland), based on the network of geodetic points covering the study area. The closing gaps obtained on the looping meshes yielded average quadratic errors of $1.2 \mathrm{~m} / \mathrm{km}$ for the determination of spatial locations ( $X$ and $Y$ coordinates) and $1.5 \mathrm{~cm} / \mathrm{km}$ for the altimetric levelling measurements $(Z$ coordinate). A Bouguer anomaly map of the study area was produced using a reduction density of $2.56 \mathrm{~g} / \mathrm{cm}^{3}$ (Fig. 2), which yielded a density anomaly that is larger than the study area. A comparison of the Bouguer anomaly and relief maps indicate that the unreasonable anomaly in the study area has been effectively suppressed (Fig. 3). The strong 
Table 2 Information on resistivities, densities, and magnetic susceptibilities (in part from Peng et al. (2016a))

\begin{tabular}{|c|c|c|c|c|}
\hline Ages & Lithology & $\begin{array}{l}\text { Specific } \\
\text { resistance } \\
(\Omega \mathrm{m})\end{array}$ & Density $\left(\mathrm{g} / \mathrm{cm}^{3}\right)$ & $\begin{array}{l}\text { Magnetic } \\
\text { susceptibility } \\
\left(4 \pi \times 10^{-6} \mathrm{SI}\right)\end{array}$ \\
\hline \multirow[t]{8}{*}{ Cretaceous } & Granite & $3.12 \times 10^{5}$ & 2.59 & 798.96 \\
\hline & Alkali feldspar granite & $1.78 \times 10^{5}$ & 2.57 & 427.33 \\
\hline & Granitic gneiss & $1.25 \times 10^{5}$ & 2.63 & 5130.09 \\
\hline & Monzogranite & $1.65 \times 10^{5}$ & 2.53 & 712.62 \\
\hline & Granite & $2.03 \times 10^{5}$ & 2.56 & 443.25 \\
\hline & Adamellite & $1.65 \times 10^{5}$ & 2.53 & 712.62 \\
\hline & Alkali feldspar granite & $1.78 \times 10^{5}$ & 2.57 & 427.33 \\
\hline & Granite & $1.14 \times 10^{5}$ & 2.53 & 268.44 \\
\hline \multirow[t]{19}{*}{ Jurassic } & Adamellite & $1.12 \times 10^{5}$ & 2.6 & 153.43 \\
\hline & Biotite adamellite & $2.66 \times 10^{5}$ & 2.61 & 451.2 \\
\hline & Shale & $1.41 \times 10^{4}$ & 2.61 & 9.02 \\
\hline & Sandstone & $2.07 \times 10^{4}$ & 2.63 & 11.41 \\
\hline & Conglomerate & $7.00 \times 10^{3}$ & 2.51 & 7.43 \\
\hline & Tuff & $1.85 \times 10^{4}$ & 2.49 & 198.15 \\
\hline & Crystal-lithic tuff & $8.92 \times 10^{3}$ & 2.63 & -12.89 \\
\hline & Monzogranite & $2.12 \times 10^{5}$ & 2.60 & 14.32 \\
\hline & Biotite granite & $1.85 \times 10^{5}$ & 2.73 & 205.31 \\
\hline & Monzogranite & $1.39 \times 10^{5}$ & 2.59 & 25.46 \\
\hline & Monzogranite & $1.40 \times 10^{5}$ & 2.56 & 88.33 \\
\hline & Biotite monzogranite & $2.66 \times 10^{5}$ & 2.61 & 451.20 \\
\hline & Monzogranite & $1.81 \times 10^{5}$ & 2.56 & -9.55 \\
\hline & Granite & $1.82 \times 10^{5}$ & 2.58 & 32.63 \\
\hline & Granite & $1.53 \times 10^{5}$ & 2.47 & 339.00 \\
\hline & Granite & $1.44 \times 10^{5}$ & 2.39 & 578.53 \\
\hline & Monzogranite & $2.49 \times 10^{5}$ & 2.55 & 349.35 \\
\hline & Granite & $1.46 \times 10^{5}$ & 2.80 & 1.59 \\
\hline & Granite & $1.96 \times 10^{5}$ & 2.53 & 219.95 \\
\hline \multirow[t]{2}{*}{ Middle Triassic } & Granitello & $8.41 \times 10^{4}$ & 2.61 & 531.58 \\
\hline & Granite porphyry & $1.34 \times 10^{5}$ & 2.66 & 999.97 \\
\hline Early Triassic & Granodiorite & $2.62 \times 10^{4}$ & 2.78 & 459.96 \\
\hline \multirow[t]{17}{*}{ Paleoproterozoic } & Biotite plagioclase granite & $1.28 \times 10^{5}$ & 2.59 & -11.62 \\
\hline & Biotite monzogranite & $1.77 \times 10^{5}$ & 2.61 & 7.16 \\
\hline & Granite & $1.73 \times 10^{5}$ & 2.48 & -4.14 \\
\hline & Granite & $2.05 \times 10^{5}$ & 2.57 & -2.71 \\
\hline & Porphyritic granite & $1.77 \times 10^{5}$ & 2.56 & 16.23 \\
\hline & Granite & $2.39 \times 10^{5}$ & 2.56 & 12.41 \\
\hline & Granite & $1.88 \times 10^{5}$ & 2.47 & 15.12 \\
\hline & Granite & $1.47 \times 10^{5}$ & 2.61 & -15.76 \\
\hline & Biotite granite & $1.54 \times 10^{5}$ & 2.65 & -4.46 \\
\hline & Biotite plagioclase granite & $1.78 \times 10^{5}$ & 2.70 & 8.91 \\
\hline & Biotite adamellite & $1.50 \times 10^{5}$ & 2.53 & -23.40 \\
\hline & Monzogranite & $2.04 \times 10^{5}$ & 2.59 & -11.62 \\
\hline & Moyite & $1.70 \times 10^{5}$ & 2.58 & 1.59 \\
\hline & Granodiorite & $1.35 \times 10^{5}$ & 2.68 & 1.86 \\
\hline & Marble & $1.69 \times 10^{5}$ & 2.79 & -20.69 \\
\hline & Monzogranite & $2.13 \times 10^{5}$ & 2.57 & 432.11 \\
\hline & Monzogranite & $1.81 \times 10^{5}$ & 2.65 & 2.39 \\
\hline
\end{tabular}


Table 2 (continued)

\begin{tabular}{|c|c|c|c|c|}
\hline Ages & Lithology & $\begin{array}{l}\text { Specific } \\
\text { resistance } \\
(\Omega \mathrm{m})\end{array}$ & Density $\left(\mathrm{g} / \mathrm{cm}^{3}\right)$ & $\begin{array}{l}\text { Magnetic } \\
\text { susceptibility } \\
\left(4 \pi \times 10^{-6} \mathrm{SI}\right)\end{array}$ \\
\hline & Granite & $1.34 \times 10^{5}$ & 2.57 & -30.56 \\
\hline & Monzogranite & $1.87 \times 10^{5}$ & 2.58 & -19.42 \\
\hline & Granite & $1.84 \times 10^{5}$ & 2.57 & -11.62 \\
\hline & Granite & $1.95 \times 10^{5}$ & 2.57 & -23.08 \\
\hline & Biotite plagiogranite & $1.28 \times 10^{5}$ & 2.59 & 12.41 \\
\hline & Biotite adamellite & $1.77 \times 10^{5}$ & 2.61 & 7.16 \\
\hline & Ganite & $1.73 \times 10^{5}$ & 2.48 & 15.12 \\
\hline & Moyite & $1.70 \times 10^{5}$ & 2.58 & 1.59 \\
\hline & Amphibolite & $1.15 \times 10^{5}$ & 2.68 & 11.14 \\
\hline & Leptynite & $1.96 \times 10^{4}$ & 2.85 & 13 \\
\hline & Gneiss & $1.70 \times 10^{4}$ & 2.79 & 29.44 \\
\hline & Marble & $3.87 \times 10^{4}$ & 2.7 & -10.88 \\
\hline & Leucoleptite & $4.67 \times 10^{4}$ & 2.74 & -3.45 \\
\hline & Mica schist & $2.79 \times 10^{4}$ & 2.69 & 62.55 \\
\hline & Leptynite & $2.44 \times 10^{4}$ & 2.81 & 29.18 \\
\hline & Mica schist & $5.69 \times 10^{4}$ & 2.8 & 58.09 \\
\hline & Leptynite (containing graphite) & $1.11 \times 10^{5}$ & 2.94 & 11.94 \\
\hline & Leptynite & $2.12 \times 10^{4}$ & 2.82 & 309.29 \\
\hline & Marble & $6.69 \times 10^{4}$ & 2.69 & -1.33 \\
\hline & Marble & $5.00 \times 10^{4}$ & 2.71 & -6.9 \\
\hline & Leucoleptite & $1.07 \times 10^{4}$ & 2.68 & -3.98 \\
\hline Archean & Monzogranite & $1.26 \times 10^{5}$ & 2.60 & 23.87 \\
\hline
\end{tabular}

Table 3 Classification of physical parameters (cited from Peng et al. (2016a))

\begin{tabular}{llll}
\hline Classes & Resistivity $(\boldsymbol{\Omega} \mathbf{m})$ & Density $\left(\mathbf{g} / \mathbf{c m}^{\mathbf{3}}\right)$ & $\begin{array}{l}\text { Magnetic } \\
\text { susceptibility } \\
\left.\mathbf{( 4 \pi} \times \mathbf{~ 1 0 ^ { - 6 }} \mathbf{S I}\right)\end{array}$ \\
\hline High/strong & $120,000-270,000$ & $2.71-2.85$ & $200-1000$ \\
Intermediate & $60,000-120,000$ & $2.68-2.70$ & $20-200$ \\
Low/weak & $8000-60,000$ & $2.48-2.67$ & -50 \\
\hline
\end{tabular}

negative anomalies correlate mainly to Mesozoic granites, whereas the largest positive anomalies correspond to the lower Proterozoic Liaohe Group and Triassic diorites.

\section{Aeromagnetic data}

Aeromagnetic data were obtained from the School of Earth Sciences, Jilin University, China, at a scale of 1:200,000. Polar processing of the data was performed to recover the symmetry of the magnetic anomalies according to the inclination and deflection of the geomagnetic field, with the magnetic anomalies being set equal to those above the source of the field, thereby enabling an accurate interpretation of the data.

The geomagnetic field possessed an inclination of $58.82^{\circ}$ and a declination of $-8.17^{\circ}$ (Peng et al. 2016b). The large magnetic anomaly shifted northward and its amplitude increased in the reduced-to-pole aeromagnetic data, which suggests that these polarprocessed data are reliable (Fig. 4). 
Table 4 Physical parameters characteristics of intrusive rocks or strata (cited from Peng et al. (2016a))

\begin{tabular}{|c|c|c|c|c|}
\hline Ages & Lithology & $\begin{array}{l}\text { Specific } \\
\text { resistance }\end{array}$ & Density & Magnetic susceptibility \\
\hline Cretaceous & $\begin{array}{l}\text { Adamellite, alkali feldspar granite, } \\
\text { granite }\end{array}$ & High & Weak & Strong \\
\hline \multirow[t]{2}{*}{ Jurassic } & Adamellite, biotite adamellite & High & Weak & Intermediate/strong \\
\hline & $\begin{array}{l}\text { Shale, sandstone, conglomerate, tuff, } \\
\text { sandstone, crystal-lithic tuff }\end{array}$ & Low & Intermediate & Weak \\
\hline Middle Triassic & Granite porphyry, granitello & High & Weak & Strong \\
\hline Early Triassic & Granodiorite & High & Weak & Strong \\
\hline \multirow[t]{2}{*}{ Paleoproterozoic } & $\begin{array}{l}\text { Biotite plagiogranite, biotite adamellite, } \\
\text { granite, moyite, amphibolite }\end{array}$ & High & Weak & Weak \\
\hline & $\begin{array}{l}\text { Gneiss, marble, leucoleptite, mica } \\
\text { schist, leptynite }\end{array}$ & Low & Strong & Intermediate \\
\hline Archean & Granitic gneiss & High & Weak & Intermediate \\
\hline
\end{tabular}

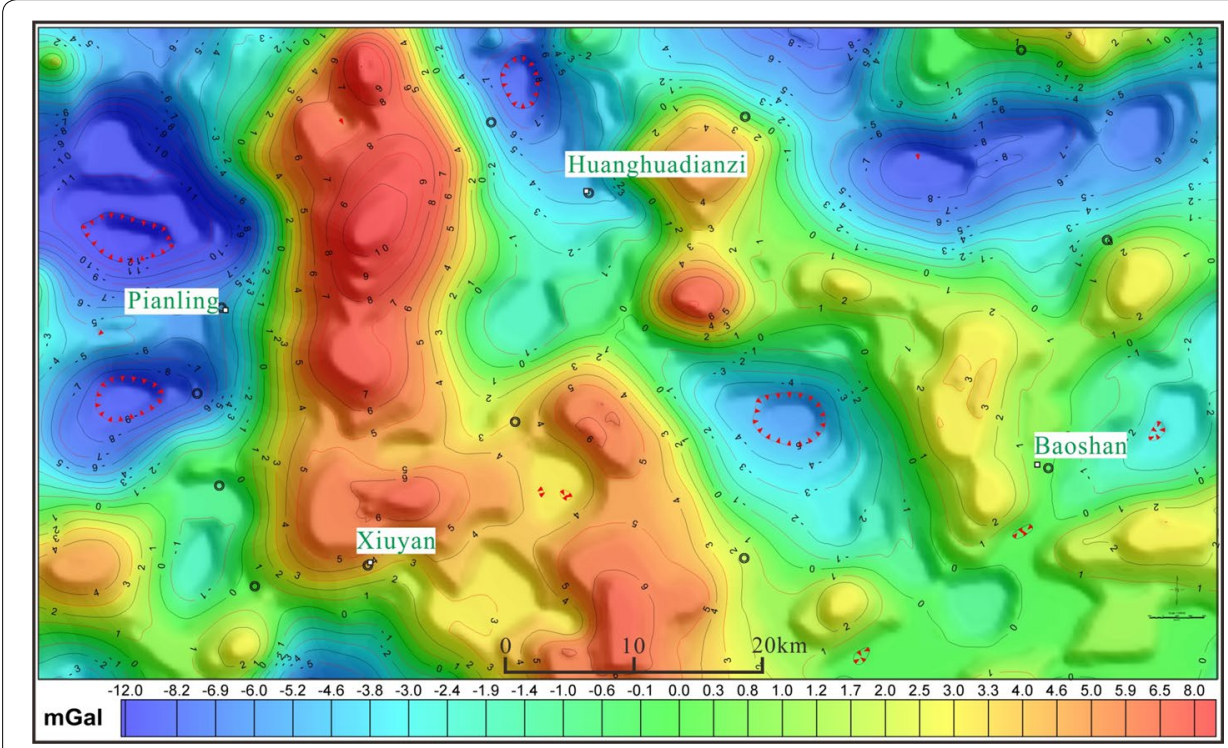

Fig. 2 Regional Bouguer gravity anomaly map of the study area, the circles of red triangles denote the locations of extremely low values

The primary magnetic anomaly in the study area trends NE-SW. The trends of these anomalies are related to the orientations of the Mesozoic and Cenozoic strata as well as intrusions. The high-amplitude NE-SW magnetic anomaly corresponds to a large fault that crosses the study area.

\section{Euler deconvolution}

Any three-dimensional function $f(x, y, z)$ is said to be homogeneous of degree $n$ if the function obeys the following expression:

$$
f(t x, t y, t z) t^{n} f(x, y, z)
$$




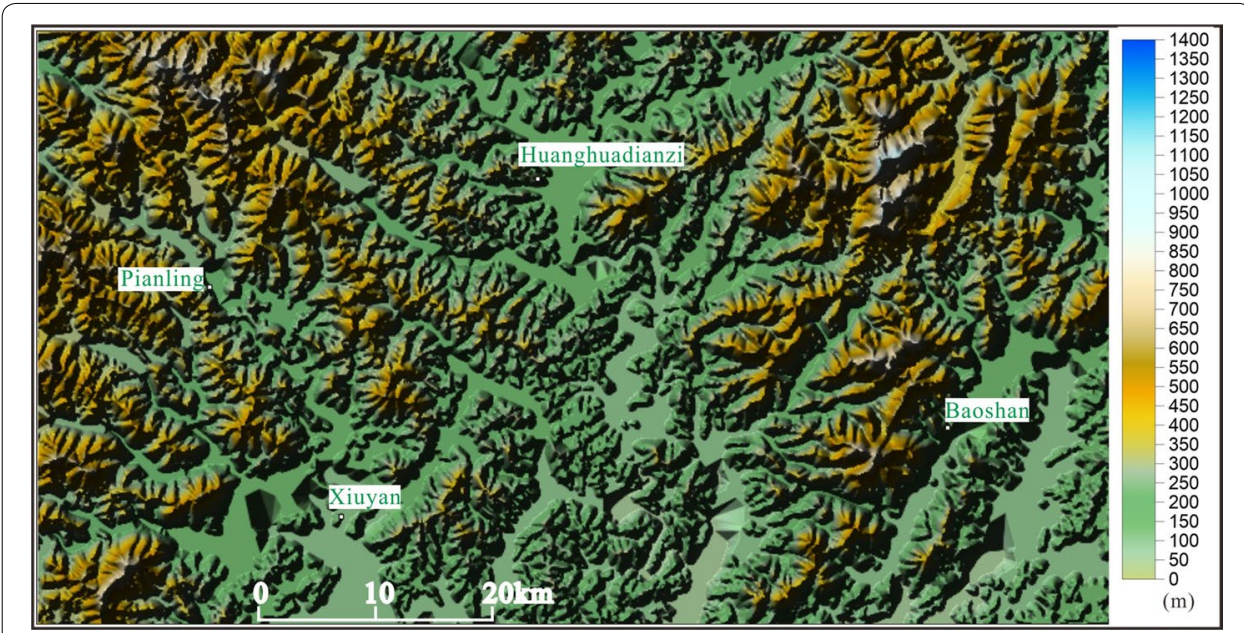

Fig. 3 Relief map of the study area

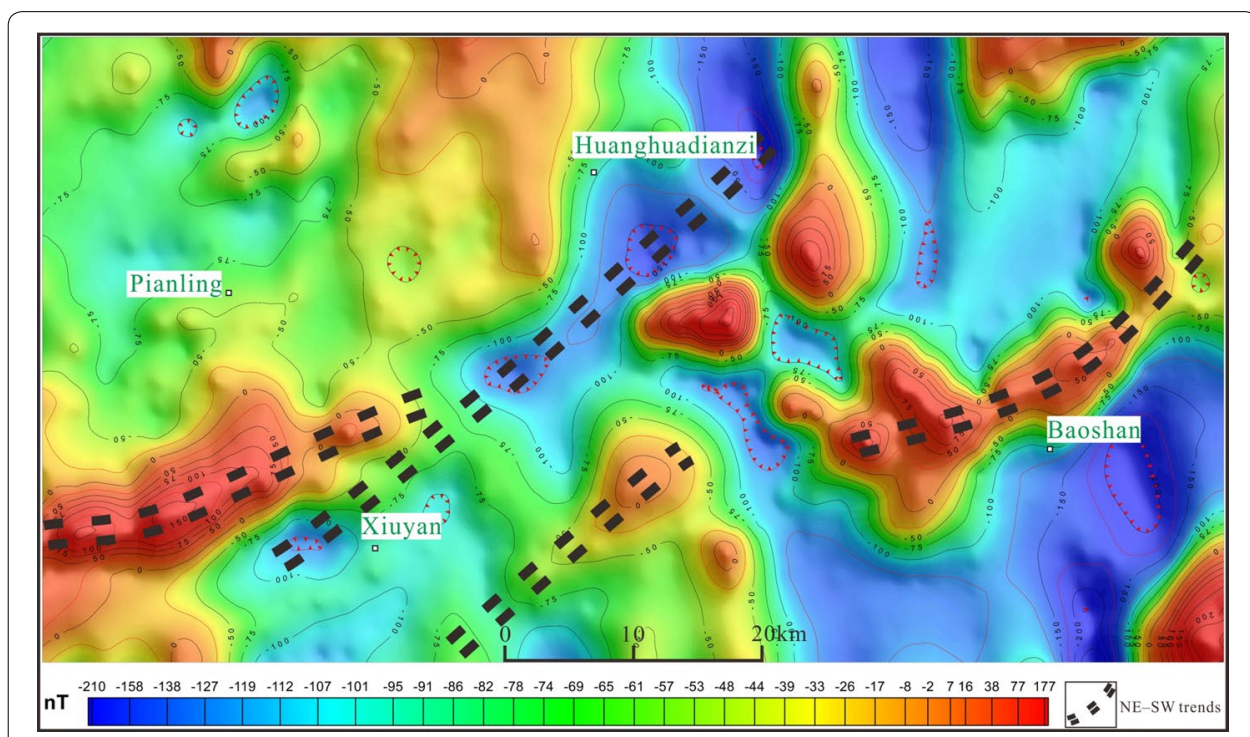

Fig. 4 Aeromagnetic Reduction to the Pole (RTP) of the study area, the circles of red triangles denote the locations of extremely low values

This expression also satisfies Euler's equation, which is defined as follows:

$$
x \frac{\partial f}{\partial x}+y \frac{\partial f}{\partial y}+z \frac{\partial f}{\partial z}=n f
$$

When analysing potential field data (e.g., magnetic data in this instance), Euler's equation can be rewritten as

$$
\frac{\partial f}{\partial x}\left(x-x_{0}\right)+\frac{\partial f}{\partial y}\left(y-y_{0}\right)+\frac{\partial f}{\partial z}\left(z-z_{0}\right)=N(B-T),
$$

where $\left(x_{0}, y_{0}, z_{0}\right)$ is the position of a magnetic source, $T$ is the total magnetic field, $B$ is a regional value of $T,(x, y, z)$ is the measurement position and $N$ is a structural index 


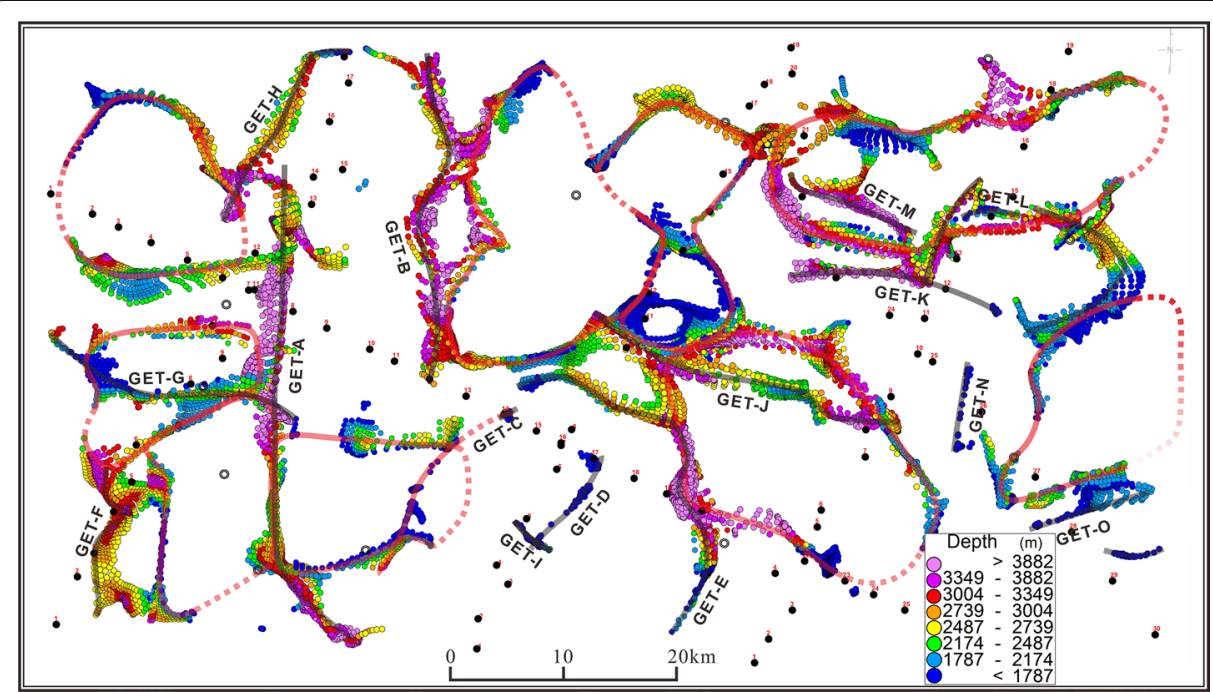

Fig. 5 Euler deconvolution of the gravity data indicating the Euler solutions for depths (1787-3882 m). The colored circle indicates the depth to gravity source and the center of the circle indicates the position of the source. The main Gravity Euler Trends (GET) are indicated

that represents the degree of homogeneity, which is a measure of the rate of change with distance from the potential field. Note that $N$ in this expression is equivalent to $-n$ in Euler's equation.

It can easily be shown that simple magnetic and gravity models conform to Euler's equation (Thompson 1982). We can determine an optimum source location $\left(x_{0}, y_{0}, z_{0}\right)$ by solving Euler's equations for a given set of observed total field data and index $N$ via a least-squares inversion of the data, with this inversion process often referred to as Euler deconvolution.

A suitable value of the structural index is needed to ensure the successful application of the Euler deconvolution. This is achieved by either experience in the Euler deconvolution method, trial and error, or using an index that produces the best clustering (Reid 1995; Pilkington and Keating 2004; Jaffal et al. 2010). Therefore, we apply the Euler deconvolution method to gravity and magnetic data to calculate the spatial distribution of fractures throughout the rock mass (Figs. 5, 6).

We use minimum curvature gridding for the gravity and aeromagnetic data gridding, and then employ the Geosoft software for the Euler deconvolution calculation using the following predefined parameters: maximum depth tolerance of $3 \%$, window size of 15, and structural indices of 0 and 1 for the gravity and aeromagnetic data, respectively.

The structural index value should be between 0 and 1 for the gravity data (Li and Xue 2015), with 0 representative of a dyke (rock mass), sill, or step, and 1 representative of a cylinder ( $\mathrm{Lu}$ et al. 2009). A comprehensive comparison of the gravity field with the known geological information of the region, targeting the structural and physical properties of the deeper main rock masses, indicates that a structure index value of 0 is ideal for our gravity analysis. 


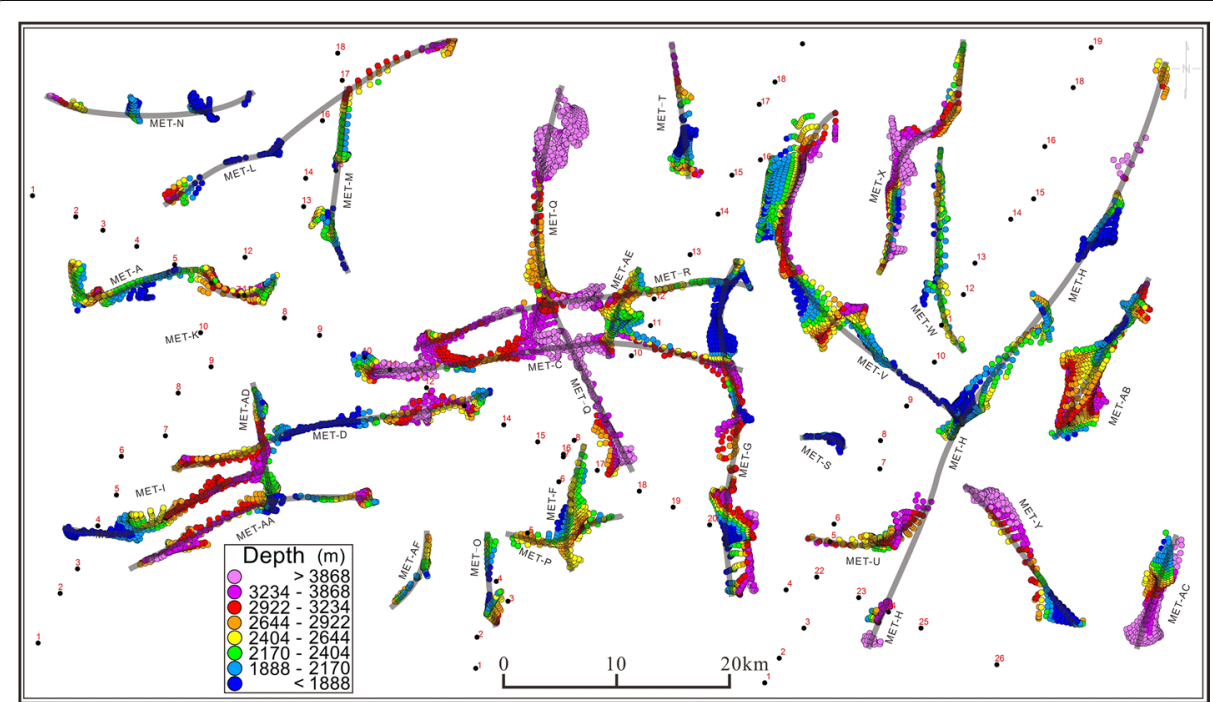

Fig. 6 Euler deconvolution of the magnetic data indicating the Euler solutions for depths (2170-3868 m). The colored circle indicates the depth to the magnetic source and the center of the circle indicates the position of the source. The main Magnetic Euler Trends (MET) are indicated

A structure index value between 0 and 1 is generally selected to highlight the spatial extent of faults in magnetic data (Li and Xue 2015). Fairhead et al. (1994) and $\mathrm{Lu}$ et al. (2009) indicated that the index value of small-scale faults is relatively small (e.g., 0.2), whereas that of deeper and/or large faults is relatively large (e.g., 0.5). Reid (1995) suggested that a structural index value of 1 should be used for thin-plate geological bodies. Since deep-seated faults are thin-plate geological bodies, and our goal is to highlight the distribution of deep-seated faults at depth, we select a structure index value of 1 for our aeromagnetic analysis.

\section{Acquisition and processing of non-seismic geophysical data}

High-resolution gravity and magnetic surveys, in combination with magnetotelluric sounding (MT) surveys, provide an effective means of imaging and characterising deep geological structures. We measured new non-seismic geophysical data and created three non-seismic geophysical profiles (NSGPs) between 2012 and 2014 to image the deep geologic structure of the Liaodong area (Figs. 7, 8, 9). A Burris-type high-accuracy gravimeter (ZLS, USA) was used at a distance of 100-250 $\mathrm{m}$ from the measuring point. A high-accuracy microcomputer proton magnetometer (GEM-19T; GEM Systems, Canada) was used to obtain measurements at the same locations as in the gravity survey. A V5-2000 MT system (Phoenix Geophysics, Canada) was used for the MT survey, with a dot pitch of 3-5 km. The MT measurements were acquired over 12-h intervals, with a signal-to-noise ratio of $>95 \%$ for the captured apparent resistivity curve based on the quality classification standard. 


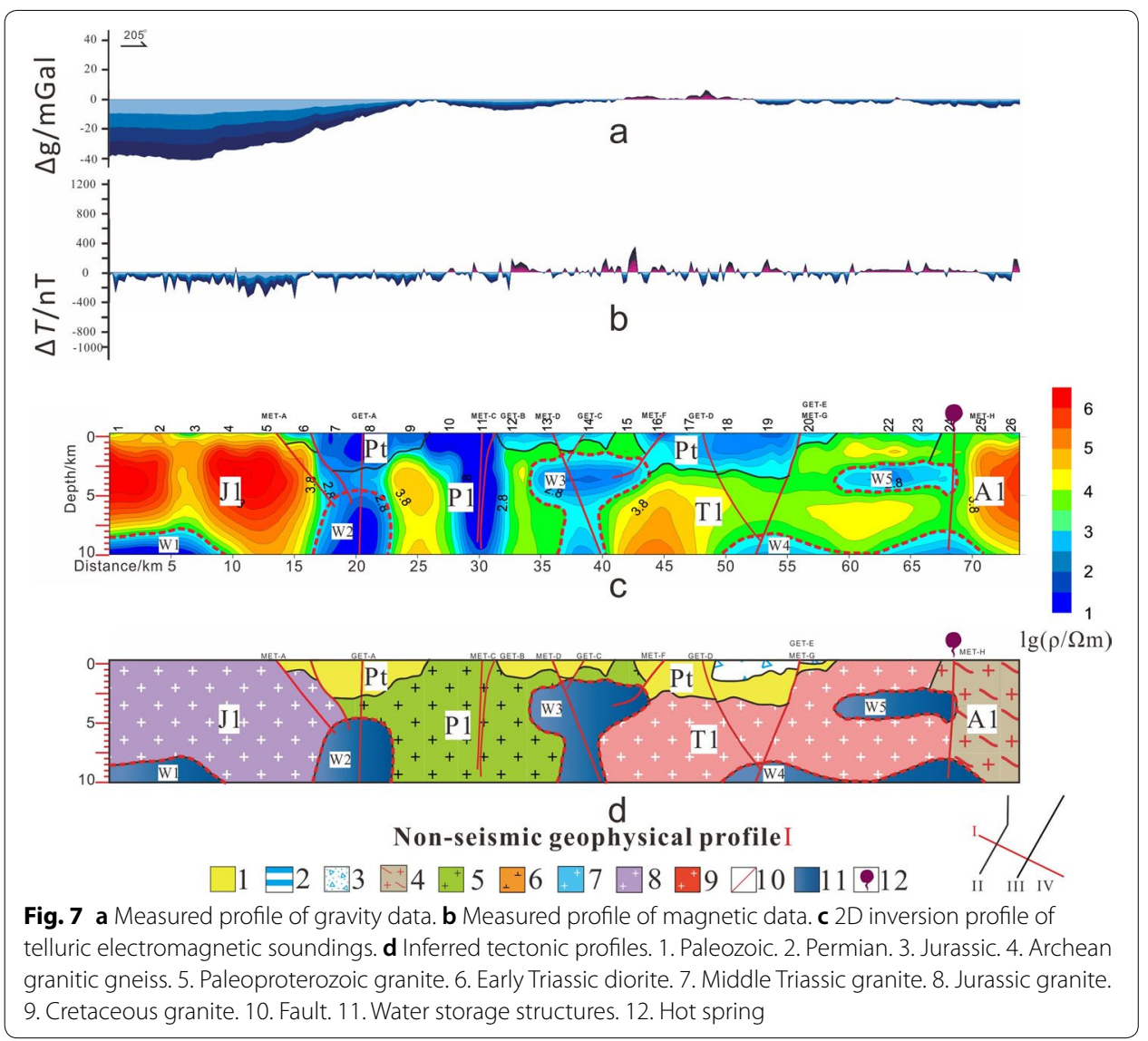

\section{Results and discussion}

\section{Deep geological structures inferred from non-seismic geophysical profiles}

We have identified the deep structure of the Liaodong area based on the apparent differences between the NSGPs and the surficial geological data. The gravity and aeromagnetic profiles show general field source anomalies, whereas the MT profiles capture two-dimensional geological information. We have, therefore, placed a higher weighting on the MT results in our interpretations, with the gravity and magnetic profiles serving as complementary datasets to validate our interpretations.

The geological body J1 (Fig. 7) is characterised by a weak gravity anomaly ( -40 to $-20 \mathrm{mGal}$ ) and a high resistivity $\left(10^{3.5}\right.$ to $\left.10^{5.5} \Omega \mathrm{m}\right)$, and it corresponds to outcropping Jurassic granites. The geological body P1 (Fig. 7) has a high resistivity $\left(10^{2.8}\right.$ to $10^{3.8} \Omega \mathrm{m}$ ), a weak intermediate magnetic anomaly ( -200 to $20 \mathrm{nT}$ ) and a weak gravity anomaly ( 0 to $-15 \mathrm{mGal}$ ), with the corresponding surface rocks being Palaeoproterozoic granites. The geological body $\mathrm{T} 1$ (Fig. 7 ) has a high resistivity $\left(10^{3.5}\right.$ to $10^{4.2} \Omega \mathrm{m}$ ) and a magnetic anomaly of up to $400 \mathrm{nT}$ that correspond to outcropping Triassic granites. The geological body A1 (Fig. 7) has a high resistivity $\left(10^{3.5}\right.$ to $10^{5.5}$ $\Omega \mathrm{m}$ ) that corresponds to outcropping Neoarchaean gneiss. The geological body $\mathrm{Pt}$ (Fig. 7) has a low resistivity $\left(10^{0}\right.$ to $10^{2} \Omega \mathrm{m}$ ), a strong gravity anomaly ( -5 to 8 $\mathrm{mGal}$ ) and an intermediate magnetic susceptibility (0-400 nT), which correspond to outcropping Palaeoproterozoic Liaohe Group rocks. The geological body T2 (Fig. 8) 

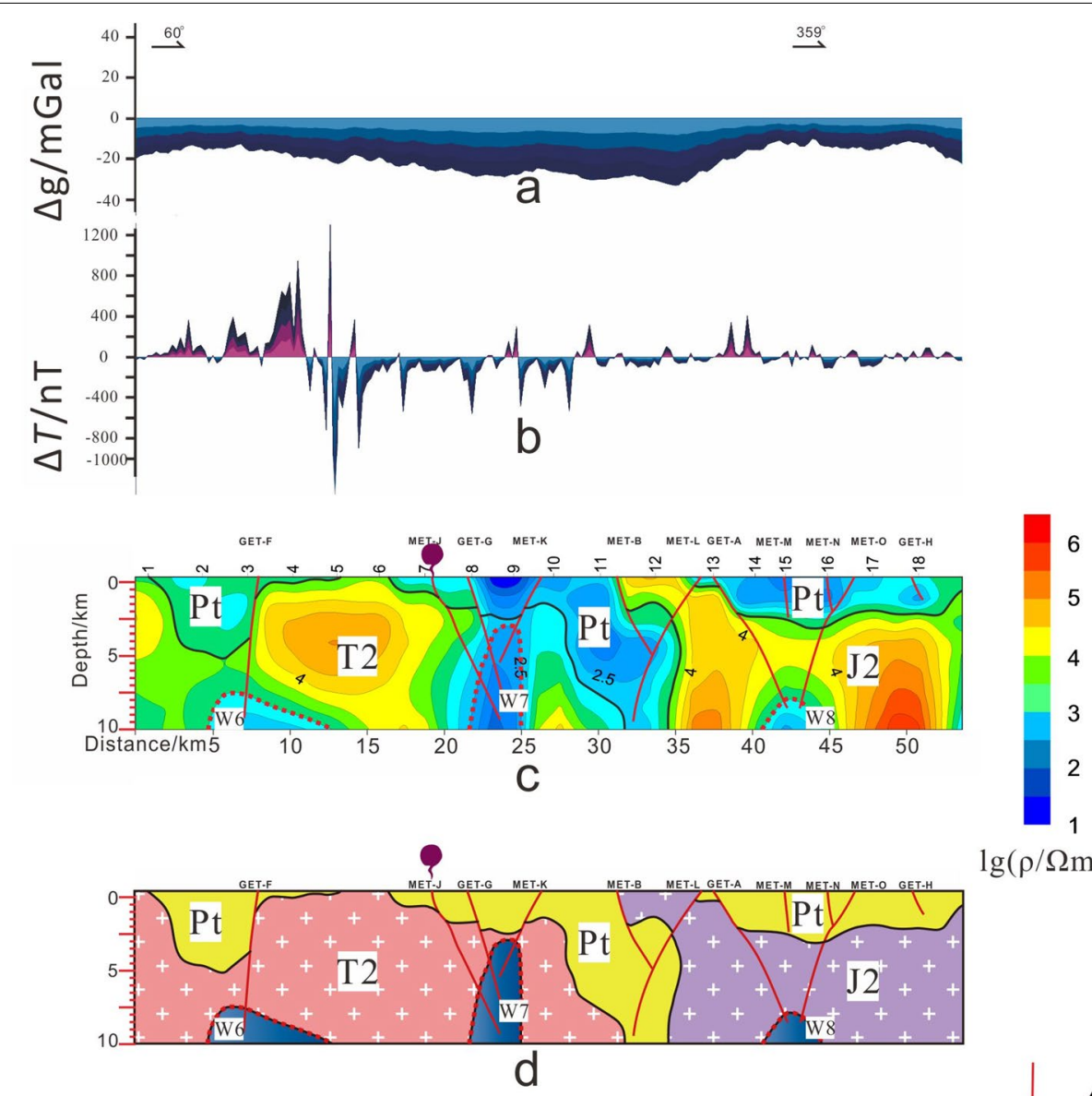

$\lg (\rho / \Omega m)$

\section{Non-seismic geophysical profile II}

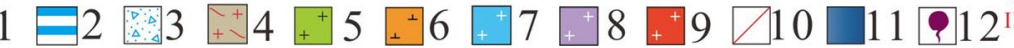

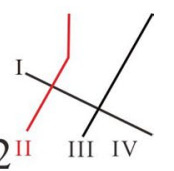

Fig. 8 a Measured profile of gravity data. b Measured profile of magnetic data. c 2D inversion profile of telluric electromagnetic soundings. $\mathbf{d}$ Inferred tectonic profiles. 1. Paleozoic. 2. Permian. 3. Jurassic. 4. Archean granitic gneiss. 5. Paleoproterozoic granite. 6. Early Triassic diorite. 7. Middle Triassic granite. 8. Jurassic granite. 9. Cretaceous granite. 10. Fault. 11. Water storage structures. 12. Hot spring

has a weak gravity anomaly ( -25 to $-20 \mathrm{mGal}$ ), a weak magnetic anomaly ( -800 to $200 \mathrm{nT})$ and a high resistivity $\left(10^{3}\right.$ to $\left.10^{5} \Omega \mathrm{m}\right)$ that correspond to outcropping Triassic granites. The geological body J2 (Fig. 8) has a high resistivity ( $10^{3.5}$ to $10^{5.5} \Omega \mathrm{m}$ ) that corresponds to outcropping Jurassic granites. The geological body Td1 (Fig. 9) has a weak gravity anomaly ( -25 to $-5 \mathrm{mGal}$ ), a weak magnetic anomaly ( -800 to $200 \mathrm{nT})$ and a high resistivity $\left(10^{3.5}\right.$ to $\left.10^{6} \Omega \mathrm{m}\right)$ that correspond to outcropping Triassic diorites. The low-resistance anomalies within the intrusive rock masses (W1W5 in NSGP 1, W6-W8 in NSGP 2 and W9-W11 in NSGP 3) may correspond to water-filled fractured zones, which we interpret as water storage structures.

\section{Hidden faults and rock masses}

We mark the Euler trends in the gravity and aeromagnetic results with line segments and overlay both trends on a map to determine their geothermal significance. 


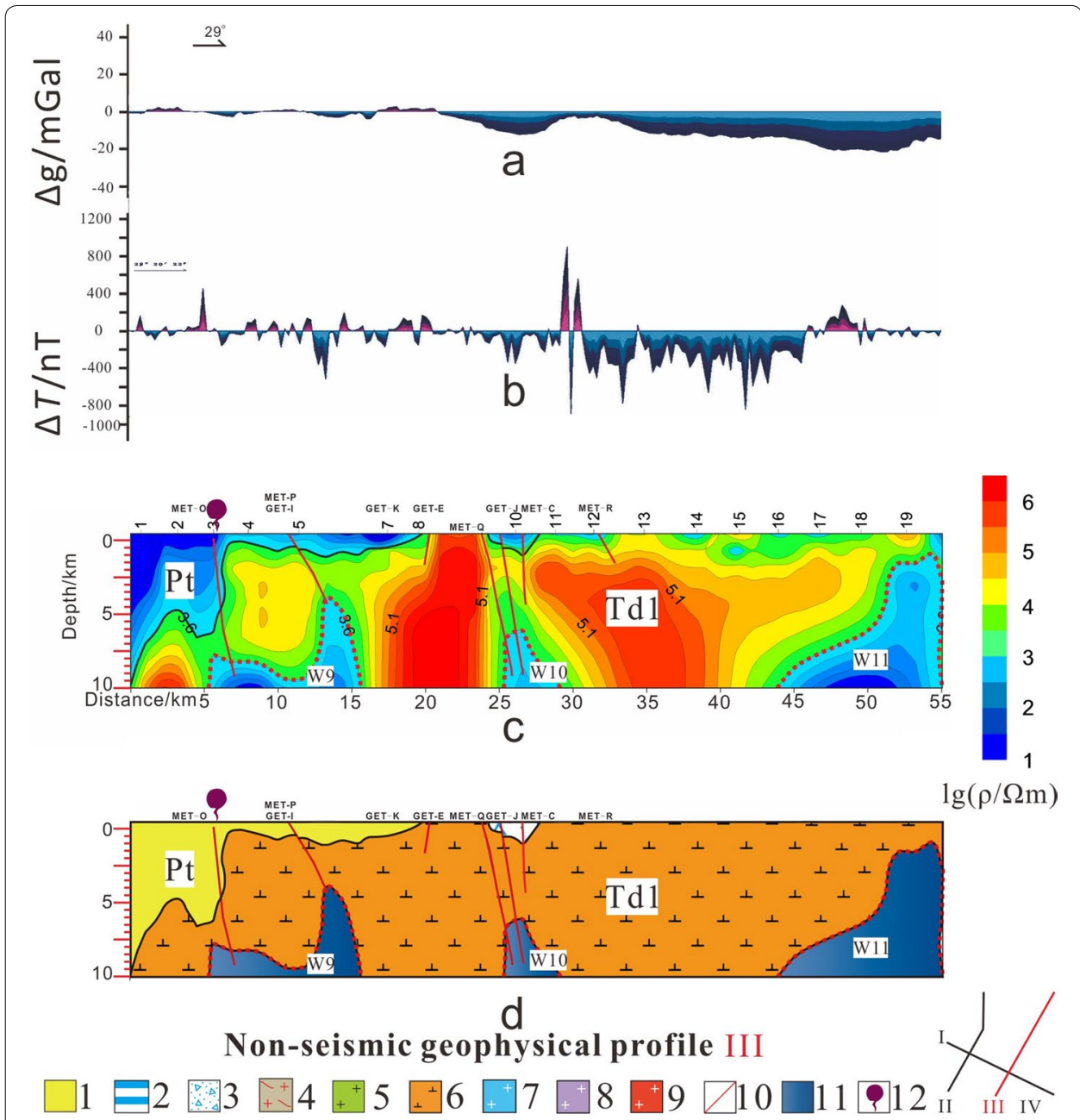

Fig. 9 a Measured profile of gravity data. b Measured profile of magnetic data. c 2D inversion profile of telluric electromagnetic soundings. $\mathbf{d}$ Inferred tectonic profiles. 1. Paleozoic. 2. Permian. 3. Jurassic. 4. Archean granitic gneiss. 5. Paleoproterozoic granite. 6. Early Triassic diorite. 7. Middle Triassic granite. 8. Jurassic granite. 9. Cretaceous granite. 10. Fault. 11. Water storage structures. 12. Hot spring

We infer the distribution of the rock mass and fractures from the Euler deconvolution of the gravity and aeromagnetic data, respectively, with the tectonic lineations corresponding to the boundaries of, and fractures in, the known rock masses. We first compare the locations of the main rock masses and consider that the closed tectonic lines calculated by gravity Euler deconvolution correspond to the spatial extent of the deep rock masses. For example, GET-CA (Gravity Euler Trend-circle A) corresponds to Jurassic granite, GET-CB, GET-CC and GET-CH correspond to Middle Triassic granite, GET-CD and GET-CF correspond to Early Triassic diorite, and GET-CE corresponds to Palaeoproterozoic granite (Fig. 5). We then find that the strike of the main faults on the surface corresponds to the aeromagnetic Euler deconvolution results, such as the MET-F (Magnetic Euler Trend-F) deep fault in Fig. 6. The aeromagnetic Euler deconvolution results show that hot springs occur primarily in areas with a deeper magnetic source depth (1500-3000 m). This verifies the high accuracy of our inferred tectonic map. 


\section{Identifying the geothermal cycle system}

Several factors are necessary for the development of geothermal resources: heat storage structures, primarily in the form of underground water storage structures; heat sources with a high rate of radiogenic heat generation; and conduits through which the heated water can rise to the surface, mainly tensile fractures.

We initially inferred the distribution of fractures from the Euler deconvolution of the aeromagnetic data. We then analysed the non-seismic geophysical profiles to further delineate the faults within the study area, as well as deduce the spatial distribution of water storage structures and intrusive rocks that provide the heat.

For example, the J1 rock mass provides the heat for the W1 water storage structure, and the MET-A fracture provides a channel for the migration of the hot water to the surface, therefore, constituting a geothermal cycle system in NSGP I (Fig. 7). Similarly, the W2 water storage structure is connected to the surface by the MET-A and GET-A fractures, and the W3 water storage structure is connected to the surface by the MET-D, GET-C and GET-F fractures, which also constitute geothermal cycle systems. The W6 water storage structure is connected to the surface by the GET-F fracture, the W7 water storage structure is coupled to the surface by the MET-J, MET-K and GET-G fractures, and the W8 water storage structure is connected to the surface by the GET-A, MET-N and MET-O fractures, all of which constitute geothermal cycle systems in NSGP II (Fig. 8). In addition, the W9 water storage structure is linked to the surface by the METP, MET-H and GET-I fractures, the W10 water storage structure is connected to the surface by the GET-J fracture, and the W11 water storage structure is linked to the surface by the MET-T fracture, all of which constitute geothermal cycle systems in NSGP III (Fig. 9).

\section{Identifying the key geothermal areas}

We inferred the locations of geothermally active regions and further defined the geothermal systems in the study area, thereby identifying the most promising geothermal targets. The distribution of fractures, which serve as channels for the migration of geothermal water to the surface in the geothermal systems, provides a good indicator of the target area for geothermal energy exploitation. We divided the target area into favourable and unfavourable zones based on the depth of the water storage structure, with favourable target areas comprising shallow storage structures and faults that extend to the surface. The MET-D, GET-C and MET-H faults are connected to thermal storage structures at a depth of $\sim 2 \mathrm{~km}$. This depth, combined with previous research results, suggests that the temperatures of the $\mathrm{A}, \mathrm{B}, \mathrm{C}$ and $\mathrm{D}$ areas are $\sim 50,48,46$ and $\sim 32{ }^{\circ} \mathrm{C}$, respectively, with $\mathrm{A}$ and $\mathrm{B}$ identified as the target areas with the highest exploitation value (Fig. 10).

\section{Correlation with seismic results}

The non-seismic geophysical results from this study are compared with the seismological results (Zheng et al. 2018) across the study area to evaluate the effectiveness of the non-seismic geophysical observations in characterising the geothermal energy potential of deep geological structures, with similar interpretations obtained. For example, a relatively low-velocity zone is observed in the vicinity of the source area below $15 \mathrm{~km}$ 


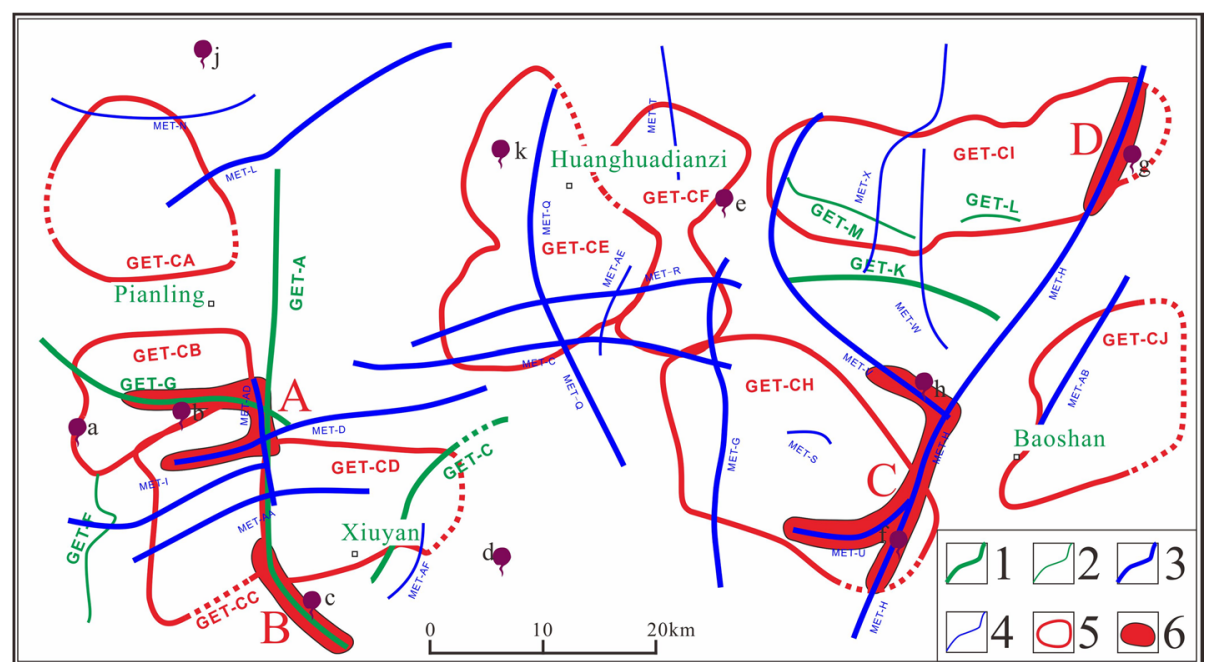

Fig. 10 1. Major faults deduced from the Euler deconvolution of gravity (GET-). 2. Minor faults deduced from the Euler deconvolution of gravity (GET-). 3. Major faults deduced from the aeromagnetic Eulerian deconvolution (MET-). 4. Minor faults deduced from the aeromagnetic Eulerian deconvolution (MET-). 5. The boundary of rock mass. 6 . The key geothermal areas

depth, which correlates with a high-conductivity layer (Fig. 11). The causes of this deeper low-velocity zone can be summarised as some combination of a low-velocity lithologic layer, a high geothermal gradient, and the $\mathrm{T}-\mathrm{U}$ phase transformation of quartz and/or pore fluid. Since a high geothermal gradient cannot lead to the formation of a low-velocity layer in the crust on its own, and special conditions are required for quartz phase transformation, the physical rock properties, rock porosity and pore fluid properties are the primary reasons for this low-velocity zone. Therefore, the strong correlation between this low-velocity zone and the high-conductivity layer is indicative of the pore fluid properties. The fluid might have been derived from either metamorphism-related dehydration under high temperature and pressure, magmatic water at the condensation point as mantle magma ascends through the crust (Che and Yu 2014), or meteoric water (Nakajima 2001; Zhao et al. 1996) or some water-bearing medium (McCaig 1988; Mark et al. 2004). Therefore, the strong correlation between the low-velocity zones in the seismic profiles and the water storage structures in the non-seismic geophysical profiles validates the effectiveness of inferring the geothermal energy potential via non-seismic geophysical profiling (Fig. 12).

\section{Conclusions}

This study concludes that an ideal geothermal circulation system is composed of a heat source, a water storage structure, and a fault that serves as a conduit to transport the heated water to the surface. The heat source provides heat to the water and other fluids in the water storage structure, which store the heat, and the thermal fluid rises along fractures and to the surface. The delineation of such faults, which are connected to the heat storage structure and exposed at the surface, can indicate target areas for geothermal exploitation. Therefore, we use the interpretation of non-seismic geophysical data 

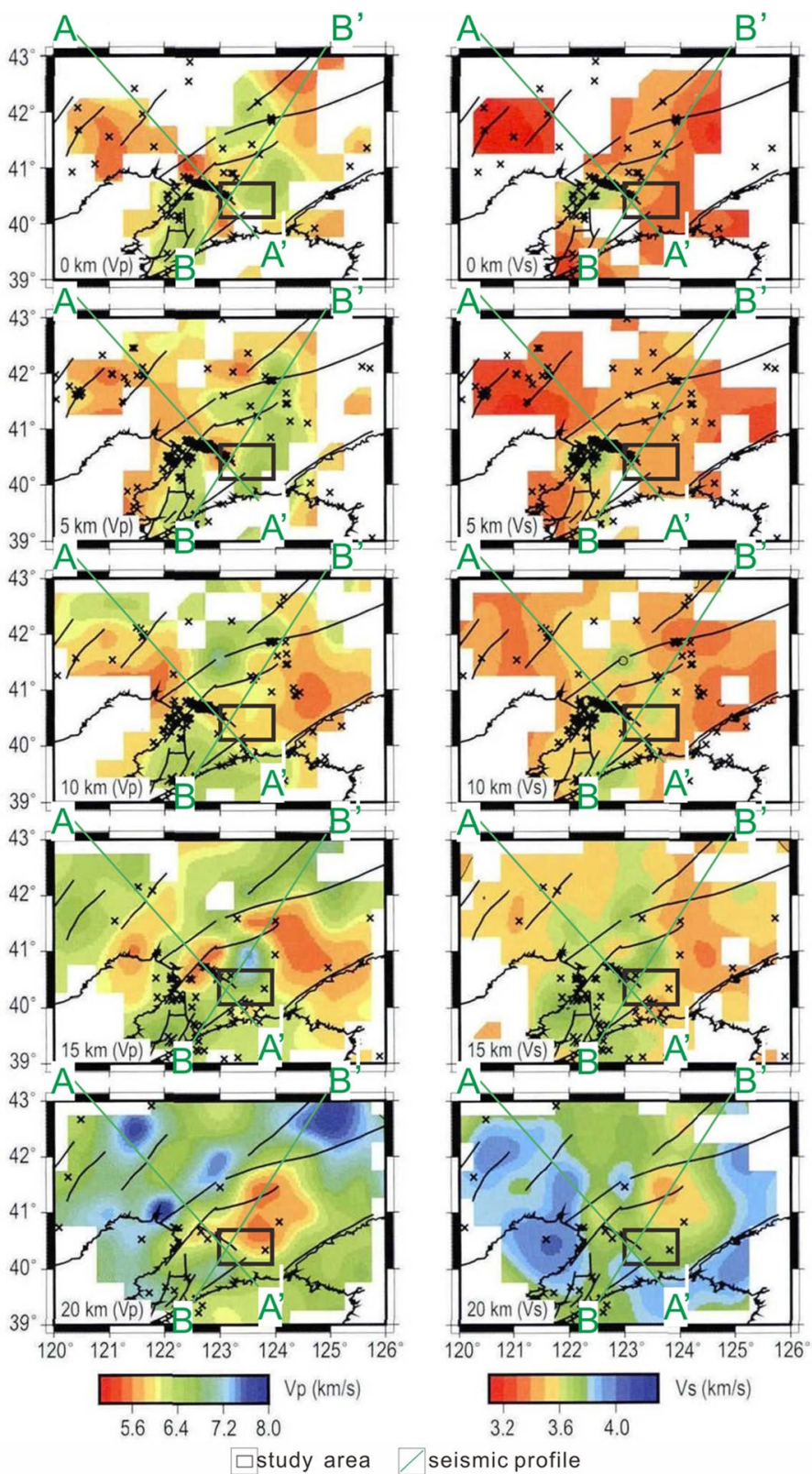

$\begin{array}{lll}3.2 & 3.6 & 4.0\end{array}$

$\Longrightarrow$ seismic profile

Fig. 11 Maps of absolute Vp and Vs at three representative layers, modified after Zheng et al. (2018). The high-coloured area denotes high resolution. The velocity scales are also shown

to infer the potential target area of geothermal energy, and finally draw the following conclusions:

- Deep geological structures can be inferred through a combination of surface geological constraints and non-seismic geophysical profiling.

- The application of Euler deconvolution to process and interpret gravity and magnetic data can reveal hidden faults and rock masses at depth. 


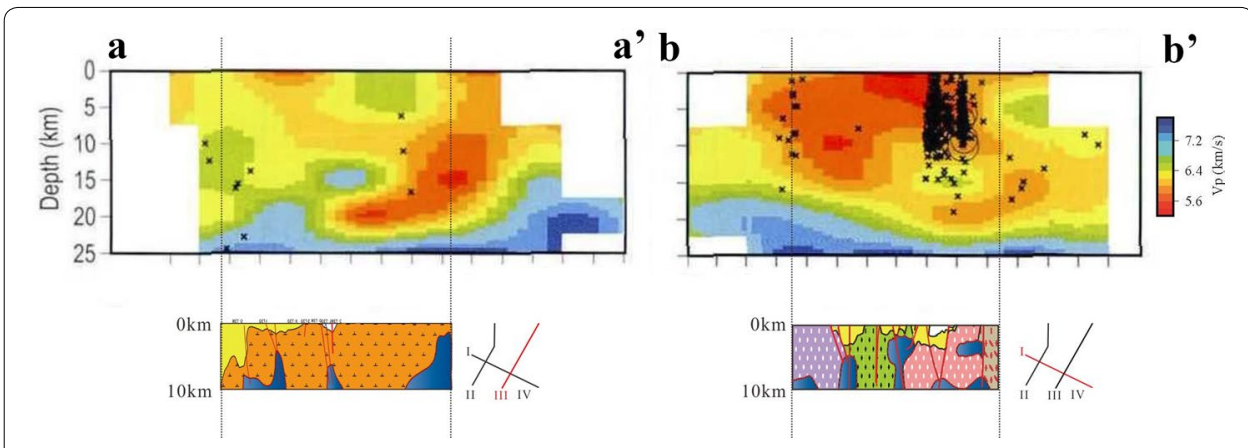

Fig. 12 Comparison of seismic and non-seismic profiles

- This study identified several geothermal systems, with at least three exhibiting favourable geothermal energy potential in the study area.

- The results show that non-seismic geophysical data can be used to identify and characterise geothermal resources. Furthermore, these data can be acquired at low cost and high operability under various environmental conditions compared with multi-channel seismic data acquisition, making non-seismic geophysical profiling a viable tool for investigating the geothermal energy potential of complex geological regions in a cost-effective manner.

\section{Acknowledgements}

We express our gratitude to Z.H. Tai and Y.G. Wang for technical support while writing the gravity processing program.

\section{Authors' contributions}

$\mathrm{CP}$ and $\mathrm{BP}$ conceived and designed the experiments; LX directed the writing of this article. HL perfected English writing and contributed analysis tools; CP analyzed the data and wrote the paper. All authors read and approved the final manuscript.

\section{Funding}

This work was funded by a pilot project titled "Deep Geological Survey of Benxi-Linjiang Area” (Project No.

1212011220247) from the 3D Geological Mapping and Deep Geological Survey of the China Geological Survey.

\section{Availability of data and materials}

They are included in the publication. Raw data are not applicable.

\section{Consent for publication}

Not applicable.

\section{Competing interests}

The authors declare that they have no competing interests.

\section{Author details}

${ }^{1}$ College of Geo Exploration Science and Technology, Jilin University, Changchun 130026, People's Republic of China. ${ }^{2}$ College of Earth Sciences, Jilin University, 2199 Jianshe Street, Changchun 130061, People's Republic of China. ${ }^{3}$ College of Geographical Sciences, Shanxi Normal University, Linfen 041004, People's Republic of China.

Received: 14 December 2018 Accepted: 4 May 2019

Published online: 15 May 2019

\section{References}

Abdel Zaher M, Saibi H, Mansour K, Khalil A, Soliman M. Geothermal exploration using airborne gravity and magnetic data at Siwa Oasis, Western Desert, Egypt. Renew Sustain Energy Rev. 2018;82:3824-32.

Arango-Galván C, Prol-Ledesma RM, Torres-Vera MA. Geothermal prospects in the Baja California Peninsula. Geothermics. 2015;55:39-57.

Barbier E. Geothermal energy technology and current status: an overview. Renew Sustain Energy Rev. 2011;6(1):3-65. Che Y, Yu J. Influence and controlling of fluid in the crust on earthquake activity. Recent developments in world seismology. 2014 
Croteau R, Gosselin L. Correlations for cost of ground-source heat pumps and for the effect of temperature on their performance. Int J Energy Res. 2015;39(3):433-8.

Dincer I, Acar C. A review on clean energy solutions for better sustainability. Int J Energy Res. 2015;39(5):585-606.

Fairhead JD, Bennett KJ, Gordon DRH, et al. Euler: beyond the "black box". In: SEG technical program expanded abstracts, vol. 13, no. 1. 1994. p. 1679.

Fridleifsson IB. Geothermal energy for the benefit of the people. Renew Sustain Energy Rev. 2001;5(3):299-312.

He L. Thermal regime of the North China Craton: implications for craton destruction. Earth Sci Rev. 2015;140:14-26.

Hersir GP, et al. Krýsuvík high temperature geothermal area in SW Iceland: geological setting and 3D inversion of magnetotelluric (MT) resistivity data. J Volcanol Geotherm Res. 2018 (in press).

Hu SB, He LJ, Wang JY. Compilation of heat flow data in the china continental area. Chin J Geophys. 2001;44:604-18.

Huang ZL. Gravity-magnetic-magnetotelluric exploration for petroleum. Dongying: Industry Petroleum Press; 1998. p. 1-396 (in Chinese).

Jaffal M, El Goumi N, Kchikach A, Aiff T, Khattach D, Manar A. Gravity and magnetic investigations in the Haouz basin, Morocco. Interpretation and mining implications. J Afr Earth Sci. 2010;58(2):331-40.

Jiang G, et al. Terrestrial heat flow of continental China: updated dataset and tectonic implications. Tectonophysics. 2019;753:36-48.

Kütahyali C, Cobos J, Rondinella WV. Comparison of fluorescence-enhancing reagents and optimization of laser fluorimetric technique for the determination of dissolved uranium. J Radioanal Nucl Chem. 2011;287(1):1-5.

Li W. The influence of geothermal features and radioactive heat production of rocks to potential of geothermal resources in Eastern area of Liaoning Province. Changchun: Jilin University; 2015.

Li Q, Chen LQ. Study on stratum structure characteristics in TC Basin using gravity, magnetic and electric data. Geophys Prospect Petrol. 2013:52(1):104-12

Li Z, Chen B. Geochronology and geochemistry of the Paleoproterozoic meta-basalts from the Jiao-Liao-Ji Belt, North China Craton: implications for petrogenesis and tectonic setting. Precambr Res. 2014;255:653-67.

Li W, Xue L. Heat production rate of radioactivity in rocks. Int J Earth Sci Eng. 2015;8(1):59-66.

Li S, Zhao G. SHRIMP U-Pb zircon geochronology of the Liaoji granitoids: constraints on the evolution of the Paleoproterozoic Jiao-Liao-Ji belt in the Eastern Block of the North China Craton. Precambr Res. 2007;158(1-2):1-16

Li SZ, Zhao G, Sun M, et al. Deformational history of the Paleoproterozoic Liaohe Group in the Eastern Block of the North China Craton. J Asian Earth Sci. 2005;24(5):659-74.

Li SZ, Zhao G, Sun M, et al. Are the South and North Liaohe Groups of North China Craton different exotic terranes? Nd isotope constraints. Gondwana Res. 2006;9(1):198-208.

Li SZ, Zhao GC, Santosh M, et al. Palaeoproterozoic tectonothermal evolution and deep crustal processes in the Jiao-LiaoJi Belt, North China Craton: a review. Geol J. 2011:46(6):525-43.

Li S, Zhao G, Santosh M, et al. Paleoproterozoic structural evolution of the southern segment of the Jiao-Liao-Ji Belt, North China Craton. Precambrian Res. 2012;200-203(4):59-73.

Li W, Xue L, Zhang W, et al. The geothermal model of strike slip fault system in Dandong, Liaoning Province, China. In: International conference of information science and management engineering. 2014. p. 1641-50.

Lior N. Sustainable energy development: the present (2009) situation and possible paths to the future. Energy. 2010;35(10):3976-94.

Liu DY, Nutman AP, Compston W, Wu JS, Shen QH. Remnants of $\geq 3800$ Ma crust in the Chinese part of the Sino-Korean craton. Geology. 1992;20(4):339.

Liu Z, Wang W, et al. Primary study on Geological characteristics of Nuanquan geothermal field in Liaoning Xiuyan. Technol Pioneers. 2014;7:241-2 (in Chinese).

Lu LZ, Xu XC, Dong YS. Three main styles of early precambrian metamorphic evolution in northern Sino-Korea craton and their geodynamics. Geol J China Univ. 1998;4:1-10.

Lu XP, Wu FY, Guo JH, et al. Zircon U-Pb geochronological constraints on the Paleoproterozoic crustal evolution of the Eastern Block in the North China Craton. Precambrian Res. 2006;146(3):138-64.

Lu BL, Fan MN, Zhang YQ. The calculation and optimization of structure index in Euler deconvolution. Prog Geophys. 2009;24(3):1027-31.

Mark G, Williams PJ, Boyce AJ. Low-latitude meteoric fluid flow along the Cloncurry Fault, Cloncurry district, NW Queensland, Australia: geodynamic and metallogenic implications. Chem Geol. 2004;207(1-2):0-132.

Mccaig AM. Deep fluid circulation in fault zones. Geology. 1988;16(10):867-70.

Meng E, Liu F, Liu P, et al. Depositional ages and tectonic implications for South Liaohe Group from Kuandian area in northeastern Liaodong Peninsula, Northeast China. Acta Petrologica Sinica. 2013;29(7):2465-80.

Mohammadzadeh Moghaddam M, Mirzaei S, Nouraliee J, et al. Integrated magnetic and gravity surveys for geothermal exploration in Central Iran. Arab J Geosci. 2016;9(7):506.

Nakajima J. Seismic imaging of arc magma and fluids under the central part of northeastern Japan. Tectonophysics. 2001;341:1-7.

Peng QM, Palmer MR. The Palaeoproterozoic boron deposits in eastern Liaoning, China: a metamorphosed evaporite. Precambr Res. 1995;72:185-97.

Peng C, Xue LF, Zhu M, et al. The location and evolution of the tectonic boundary between the Paleoproterozoic Jiao-Liao-Ji Belt and the Longgang Block, northeast China. Precambrian Res. 2016a;272:18-38.

Peng C, Xue LF, Liu ZH, et al. Application of the non-seismic geophysical method in the deep geological structure study of Benxi-Huanren area. Arab J Geosci. 2016b;9(4):310.

Pilkington M, Keating P. Contact mapping from gridded magnetic data? A comparison of techniques. Explor Geophys. 2004;35(4):306.

Reid AB. Euler deconvolution, past, present and future: a review. In: SEG expanded abstracts. 1995. p. 861-3.

Song B, Nutman AP, Liu D, Wu J. 3800 to 2500 Ma crustal evolution in the Anshan area of Liaoning Province, northeastern China. Precambr Res. 1996:78(1-3):79-94. 
Tam PY, Zhao G, Liu F, et al. Timing of metamorphism in the Paleoproterozoic Jiao-Liao-Ji Belt: new SHRIMP U-Pb zircon dating of granulites, gneisses and marbles of the Jiaobei massif in the North China Craton. Gondwana Res. 2011;19(1):150-62.

Thompson DT. EULDPH: a new technique for making computer-assisted depth estimates from magnetic data. Geophys. 1982;47(1):31-7.

Wan Y, Song B, Liu D, et al. SHRIMP U-Pb zircon geochronology of Palaeoproterozoic metasedimentary rocks in the North China Craton: evidence for a major Late Palaeoproterozoic tectonothermal event. Precambrian Res. 2006;149(3):249-71.

Wang JY, Huang SP. Compilation of heat flow data in the china continental area. Seismolog Geol. 1990:12(4):351-66 (in Chinese)

Xu P, Ling S, Li C, et al. Mapping deeply-buried geothermal faults using microtremor array analysis. Geophys J Int. 2012;188(1):115-22.

Yuan L, Zhang X, Xue F, Han C, Chen H, Zhai M. Two episodes of Paleoproterozoic mafic intrusions from Liaoning province, North China Craton: petrogenesis and tectonic implications. Precambr Res. 2015;264:119-39.

Zhang QS. Geology and mineralization of the early Precambrian in China. Changchun: Jilin People's Press; 1984. pp. 196-264 (in Chinese).

Zhang $L$, et al. Magnetotelluric investigation of the geothermal anomaly in Hailin, Mudanjiang, northeastern China. J Appl Geophys. 2015;118:47-65.

Zhao G. Metamorphic evolution of major tectonic units in the basement of the North China Craton: key issues and discussion. Acta Petrologica Sinica. 2009:25(8):1772-92.

Zhao G, Zhai M. Lithotectonic elements of Precambrian basement in the North China Craton: review and tectonic implications. Gondwana Res. 2013;23(4):1207-40.

Zhao D, Kanamori H, Negishi H, et al. Tomography of the source area of the 1995 Kobe earthquake: evidence for fluids at the hypocenter? Science. 1996;274(5294):1891-4.

Zhao G, Wilde SA, Cawood PA, et al. Archean blocks and their boundaries in the North China Craton: lithological, geochemical, structural and P-T, path constraints and tectonic evolution. Precambrian Res. 2001;107(1):45-73.

Zhao G, Sun M, Wilde SA, et al. Late Archean to Paleoproterozoic evolution of the North China Craton: key issues revisited. J Asian Earth Sci. 2005;24(5):519-22.

Zhao G, Cawood PA, Li S, et al. Amalgamation of the North China Craton: key issues and discussion. Precambrian Res. 2012;222-223(12):55-76.

Zheng Q, Liu C, Tian Y, et al. Seismic imaging of the middle and upper crust by double-difference tomography: the Haicheng earthquake (Ms 7.3) in Liaoning Province. Appl Geophys. 2018;15(1):125-36.

Zhong Y, Xiao X. Preliminary study on spatial relationship between earthquakes and hot springs on Liaodong peninsula. Seismol Geol. 1990;12(4):343-50.

\section{Publisher's Note}

Springer Nature remains neutral with regard to jurisdictional claims in published maps and institutional affiliations.

\section{Submit your manuscript to a SpringerOpen ${ }^{\circ}$ journal and benefit from:}

- Convenient online submission

Rigorous peer review

- Open access: articles freely available online

- High visibility within the field

Retaining the copyright to your article

Submit your next manuscript at $\gg$ springeropen.com 